\title{
Taxation of Insolvent Companies: Empirical Evidence in Portugal ${ }^{\star}$
}

Ana Cristina dos Santos Arromba Dinis

Instituto Superior de Contabilidade e Admininistração de Coimbra, Coimbra, Portugal

Cidália Maria da Mota Lopes

Instituto Superior de Contabilidade e Administração de Coimbra, Departamento de Ciências Empresariais e Fiscalidade, Coimbra, Portugal

\author{
Alexandre Miguel Fernandes Gomes da Silva \\ Instituto Superiọr de Contabilidade e Administração de Coimbra, Departamento de Matemática e Estatística, Coimbra, Portugal \\ Pedro Miguel de Jesus Marcelino \\ Instituto Superior de Contabilidade e Administração de Coimbra, Departamento de Ciências Empresariais e Fiscalidade, Coimbra, Portugal \\ Received on 01.28.2014 - Desk acceptance on 03.18.2014- $4^{\text {th }}$ version approved on 04.16.2015
}

\section{ABSTRACT}

This article discusses the issue of taxation of insolvent companies in Portugal, particularly regarding the Portuguese tax on revenue of legal entities (IRC). For this purpose, first, some considerations on the legal framework of insolvent companies are woven and, second, their tax regime is analyzed. Then, a brief review of the main studies that, in the international context, analyze and debate major issues derived from the tax regime of insolvent companies is conducted, particularly in Brazil, Spain, United States, and Italy. Finally, there are the results of an empirical study conducted in Portugal, in 2013, which evaluates and compares the opinions of insolvency administrators (IA), the tax and customs authority (TA), and court magistrates (CM), in order to contribute to a better solution concerning business taxation under this regime. Respondents (IA, TA, CM) demonstrate objective thinking about the fact they believe it is very important that the Portuguese Code of Insolvency and Business Recovery (CIRE) and the Portuguese Code of Tax on Revenue of Legal Entities (CIRC) are modified,'now to make clear whether the settlement of property ownership of an insolvent estate is liable to the IRC, then to assign a chapter specifically devoted to the subject of taxation on insolvency in Portugal.

Keywords: insolvency, taxation, Portuguese tax on revenue of legal entities. 


\section{INTRODUCTION}

This study addresses the fiscal framework of insolvent companies regarding the Portuguese tax on revenue of legal entities (IRC), in a reality encircled by companies established or effectively managed in the Portuguese territory. It is intended to know, as already discussed by Dinis, Lopes, and Marcelino (2014), whether the insolvent estate is subject to tax liability and whether the outcome of an insolvent company's settlement of assets must be subject to taxation regarding the IRC.

The authors highlight there is no consensus among the various stakeholders in the insolvency proceedings concerning the tax liability of these companies. Because, if on the one hand "the tax and customs authority (TA) has regarded the insolvent estate as liable to taxation and, as a consequence, an insolvent company's settlement of assets is subject to taxation regarding the IRC," turn "the insolvency administrators (IA) ${ }^{1}$ argue that an insolvent company does not pursue, primarily, a commercial, industrial, or agricultural activity, and, therefore, from the moment when all goods are seized for the insolvent estate, the outcome of their liquidation is not liable to the IRC, and this viewpoint is corroborated by a part of the Portuguese jurisprudence."

Legally speaking, Law 16/2012, enacted on April 20, 2012, provided the $6^{\text {th }}$ amendment to the Portuguese Code of Insolvency and Business Recovery (CIRE) and it aimed to clarify the regime applicable to compliance with tax liabilities by insolvent companies in Portugal, particularly after decision-making with regard to business closure, a case where all tax liabilities and revenue debts should be extinguished. However, still, this theme has not been fully made clear, thus, doubts remain in the phase of settlement of property ownership of an insolvent estate.

In the economic sphere, regarding the application of the CIRE over time it can be seen that the recovery of insolvent companies failed to come true by itself, in practice, as an effective alternative to company settlement (Portugal, 2010, 2 de dezembro). In most cases, companies declared as insolvent are indeed in this situation for quite some time, and the maintenance of an insolvency plan turns out, in practice, to be just a way of delaying the settlement of a company that long ago should have been extinct.

In the accounting sphere, it is pertinent to analyze there is a widespread failure with regard to the obligation to keep books organized in insolvent companies, a situation that worsens by delaying the insolvency proceedings.

In the fiscal sphere, it is observed that the fiscal science has given more attention to the goals of equity and efficiency than to simplicity and feasibility issues or operation of the fiscal system, a situation that becomes more complex concerning the issue of taxation of insolvent companies (Lopes, 2008).

Thus, it is a significant issue that deserves to be discussed with the academic and professional community.

So, our research shows up as significant for the reasons listed below. First, to the best of our knowledge, there are not in Portugal many studies that have addressed taxation of insolvent companies and its implications. And, second, the current economic conjuncture, i.e. crisis and consequent increased number of bankruptcies and insolvencies, makes the theme pertinent, up-to-date, and relevant.

So, this article seeks to introduce a critical view of the tax regime for insolvent firms also analyzing in the international context the fiscal issue of taxation of insolvent companies, resorting to an empirical study based on a reference sample, which focuses on the profile and work developed by IA, the TA, and court magistrates (CM) in Portugal.

In order to achieve the proposed objectives, this article was structured into three sections. Subsequently there are some preliminary considerations on the legal regime of insolvent companies, a brief analysis of the fiscal regime of the insolvency proceedings in Portugal and the various studies conducted at the international level. Then, we devote our study to research methodology and data analysis, and develop the methodological aspects of our research, by performing statistical tests, in order to confirm the hypotheses, and discussing the results obtained. And, then, we make our final remarks.

\section{LEGAL REGIME OF INSOLVENT COMPANIES: SOME PRELIMINARY CONSIDERATIONS}

The legal framework of insolvent companies in Portugal is regulated by the CIRE.

The concept of insolvent estate is defined by article 46 in the CIRE. The insolvent estate is generally designed to meet the insolvency creditors' needs and it covers all assets of the insolvent company at the time insolvency is decla- red, as well as the assets and rights it acquires during the proceedings.

If the insolvent estate is not enough or when creditors are paid, the insolvency proceedings are terminated and the insolvent company can keep pursuing its activity as usual.

During the proceedings, the meeting of creditors may 
decide on the termination or maintenance of the company activity, or other businesses comprised in the insolvent estate, as defined by article 156 in the CIRE.

If the meeting of creditors decides to keep pursuing the company activity, adopting an insolvency plan, the business activity can also go on as usual. If the meeting of creditors decides to terminate business, the company enters liquidation.

\section{THE FISCAL REGIME OF INSOLVENT COMPANIES}

\subsection{Taxation of Insolvent Companies in Portugal}

The TA (Portugal, 2010, 16 de dezembro) argues that compliance with tax liability standards, even at the phase of an insolvent company's settlement of assets, will have nothing extraordinary in the light of the principles underlying taxation liable to the IRC, in accordance with the CIRC. This is so because, according to the TA, once insolvency is declared, even if a a business is terminated, it does not mean this company ceases to have revenues subject to the IRC. Hence, according to the TA, revenues are not derived only from an effective economic activity, but also from positive equity changes not reflected on the net income within the period. So, the TA advocates that after declaring insolvency, the conditions to be liable to the IRC are still checked, because what is relevant is the fact that, although it is regarded that insolvent companies do not engage in an activity, they would never become, due to insolvency, classified as entities that do not primarily pursue a commercial, industrial, or agricultural activity, in accordance with the CIRC.

Tiago (2012) advocates for the position taken by the TA and believes that in companies declared as insolvent it is not the fact that this is an insolvency proceeding that prevents revenues due to the sale of goods at prices that may, in addition to paying all debts to creditors, increase equity. As such, no reason remains to evade taxation regarding the IRC. However, the taxable profit of an insolvent company is determined in relation to the entire settlement period of the company's equity.

Nevertheless, the IA (Portugal, 2010, 16 de dezembro) interpret article 3, paragraph 4 , in the CIRC on the contrary, insofar as they think an insolvent company does not primarily pursue a commercial, industrial, or agricultural activity, when the meeting of creditors decides on the liquidation of the insolvent estate and shares the value obtained by the creditors. According to the IA, the aim is not profit, but only paying the creditors, thus there is no business operation and they claim that, since no revenues are obtained, the insolvent estate should not be subject to taxation.

In this way, according to Portugal (2007), a part of the Portuguese jurisprudence is also guided by the fact that the company settlement standards should not be confused with those concerning settlement of insolvent assets, because while the first are intended to regulate the sharing of corporate assets of a dissolved company, and settlement is made in the interest of shareholders, the latter regulate the sale of goods listed for the insolvent estate, as if consisting of executive proceedings, made in the interest of creditors. Also, in view of the concept of additional revenue, for the purposes of the IRC, and considering that taxation of revenue gain regarding the IRC is related to the economic reality made up of profit, Portugal (2003) shows that the sale of goods included in the property of a company declared as bankrupt, made in the proceedings of the settlement of a certain asset, does not refer to the concept of capital gains and capital losses provided for the CIRC and, after declaration of bankruptcy, there is no property, as such, before all goods are seized, they become a new property, a collection of assets and rights taken away from the company and it serves exclusively, after liquidated, to pay, first, the legal fees and administrative expenses, then, the credits recognized. Furthermore, it explains that only through a legal fiction someone could regard as taxable profit the outcome of property alienation related to the payment of debts that can no longer be fully paid.

As made apparent above, we may conclude that this theme constitutes a very controversial subject and it is still open to discussions and conclusions, in Portugal.

Is this a problem observed in all of the other countries in the global market?

It is the answer to this question that the subsequent section looks for.

\subsection{Taxation of Insolvent Companies:} International Comparisons and Results of Studies in Brazil, Spain, the U.S., and Italy

In the international literature, within the theme of taxation regarding companies' bankruptcy, the fiscal issue is not peaceful, too. Our focus lies on Brazil, Spain, the U.S., and Italy, as these are the countries with references to authors that we have found in our literature search, concerning the theme under study.

\subsubsection{Taxation of insolvent companies in Brazil.}

In Brazil, the institute of bankruptcy is currently regulated by the provisions of the Lei de Recuperação de Empresas e Falências [Business Reorganization and Bankruptcy Law], which provides for the extrajudicial recovery and bankruptcy of an individual entrepreneur and the corporate company. Regarding the taxation of insolvent companies in Brazil, Fernandes and Mario (2010) provide their contri- 
bution and highlight that, after bankruptcy, the bankrupt is dispossessed of its assets and the bankrupt estate emerges, as an "accounting entity for the purposes of analyses and controls," but it has no legal personality in the Brazilian positive law and it is also not equal to a "person for tax purposes." In addition, the authors state that there were several Pareceres Normativos da Secretaria da Receita Federal [Normative Opinions from the Secretariat of Federal Revenue] recognizing that the bankrupt estate was not liable to the tax standards, since it has only the nominal property of collected goods, administration is a responsibility of the court trustee. Although the Brazilian legislation has regarded many amendments to current standards, regarding taxation of a bankrupt estate, this is a very controversial subject, above all due to the fact that according to Fernandes and Mario (2010) "taxation or the lack of it for a bankrupt estate is directly related to the assumption of the economic essence of an accounting entity as opposed to the legal form personified or not, bringing up to the current context conflicting points and their possible effects." Total settlement of assets to pay creditors, as it is not possible to address the joint sale of assets as revenue, because this is only the "best value obtained" of those assets in "forced proceedings." Taxation on the resources seized for a bankrupt estate to pay off its debts has no economic support, not even legal. What is taxed is property instead of revenue and "moreover, the guarantees left over to creditors." Also, and similarly to what occurs in Portugal, according to Marques (2005), "tax" is the main link between the fiscal regime and the bankruptcy regime, but when it comes to fiscal credits, the author shows there is an order to be followed, and the credits to the court trustee and assistants, as well as the credits to service provided to the bankrupt estate, expenses, and court costs related to the bankruptcy proceedings should be paid first. Because only after complying with all of the obligations mentioned above, finally, it is possible to think of paying the "tax credit owed by the bankrupt estate." Restructuring the legal regime of insolvency was a need, with the main purpose of getting the two regimes closer. On the other hand, Spadotto (2005) claims that "tax debts" constitute a major obstacle to the economic recovery of a company and that according to the "old system, the acquirer of a company whose break was decreed subrogates the tax liabilities of the company to which alienation had fallen on," but after this "new system adopted by the lawmaker, tax debts that fall on the sale of the company's assets must not be required from the acquirer."

\subsubsection{Taxation of insolvent companies in Spain.}

In Spain, the Ley Concursal [Bankruptcy Law] establishes a single court procedure to address the proceedings triggered by the insolvency of a debtor, the so-called "concurso de acreedores" (meetings of creditors). According to Moreno-Ternero and Villar (2002) the issue of bankruptcy is aimed at the fact that there must be assigned a certain amount of a divisible good when a company has not enough to meet the requirements of all creditors. As for the tax issues raised in insolvency proceedings, concerning fiscal implications in the reform of the Ley Concursal, namely the fact that the reform was accompanied by a number of other legislative changes, such as, for instance, that derived from the Ley General Tributaria [General Tax Law], Medina (2012) shows that this change had an impact that might not generate any benefit to the "concurso de acreedores", since, by favoring the credit position of public creditors in case of bankruptcy, it ceased safeguarding the position of creditors, which is the main interest of insolvency proceedings, in order to prioritize the public interest, which comes out favored at the expense of the economic operators. The author also points out the British insolvency practice that, after the abolition of privileges to the public credits, provided a greater satisfaction of creditors, which enabled increasing their "rentas disponibles" [disposable revenue gain] and, as a consequence, their investment and consumption possibilities, thus stimulating the economy and, naturally, government's tax revenue. Escolà (2004) argues that, although the Ministry of Justice insists on highlighting that the purpose of the new regulation on bankruptcy is supporting and ensuring the continuity of viable companies that are temporarily involved in an insolvency situation, the regulation will be far from making it easier to achieve this goal, because, according to this author, payment of debts is the main objective of the new regulation.

\subsubsection{Taxation of insolvent companies in the U.S..}

The U.S. insolvency proceedings are regulated by federal law, through the Código de Falências [Bankruptcy Code]. Regarding the theme of insolvency taxation, even appealing to fiscal awareness as a last resort, Newton (2000) demonstrates the effect of tax on certain transactions, which may impose great difficulties to entities that are undergoing insolvency, as per se in a weak financial position. It is not uncommon in bankruptcy realizing taxable profits within the administration period, by selling all or a part of assets or taxable recoveries, however, net business transaction losses and other fiscal deductions are often unable to compensate in order to minimize the effect of tax. Krause and Kapiloff (1966) claim that when the bankrupt estate is created, there is a tax directly imposed against property and indirectly against creditors, by reducing their dividend in bankruptcy, so the effect of bankruptcy is transferring the tax burden from debtors to creditors. The government receives a tax due to the bankruptcy proceedings, which is obtained at the expense of creditors, hence the issue of taxable revenue, during property administration in bankruptcy, is full of considerations having a social and economic nature.

\subsubsection{Taxation of insolvent companies in Italy.}

The Italian legislation regards insolvency as a factual situation, which may lead to the declaration of insolvency or the adoption of other proceedings intended to subtract goods available to the debtor and their settlement to meet creditors' needs with the assets obtained. The formal procedures derived from insolvency are: insolvency, creditors' agreement, and settlement under court administration ("liquidazione coatta amministrativa"). Also concerning taxation, insolvency in 
Italy generates some controversy. Addressing the reform of the Italian insolvency law, Tosi (2005) highlights the usefulness of taking stock of the situation, trying to identify the lawmaker's guidelines according to innovation prospects in the tax system - the implications with a fiscal nature. And it is necessary because many of the problems that arise for identifying the treatment applicable to fiscal proceedings occur due to an overlap between tax legislation and the bankruptcy law, hence it is advantageous in this context to address issues raised in the past about fiscal discipline in insolvency proceedings that the lawmaker finally sets the regulatory framework. This is a major taxation issue of settlement of assets and the consequent satisfaction of creditors' needs, since it is the lawmaker's intent to tax only the positive outcome of the insolvency procedure, creating a definitive continuity solution for the common taxation system (Busa, 2005 as cited in Tosi, 2005). This require- ment, however, does not agree with the settlement purpose, particularly the rule in force in bankruptcy proceedings. This is so because the ultimate solution for the activity of a company undergoing insolvency is its settlement, thus there is no reason to worry about taxation; business activity after insolvency should not be liable to taxation, because this imposition is regarded as unjustifiable.

\subsection{Concluding Notes}

The literature review conducted seems to lead us to conclude there are actually many doubts regarding the fiscal framework of an insolvent company, particularly when the decision is estate settlement. It is a controversial debate that goes beyond the case of Portugal, as we can see.

Table 1 summarizes the findings of the several authors addressed in this study.

Table 1 Comparative analysis of the main approaches to taxation of insolvent companies

\begin{tabular}{|c|c|c|c|}
\hline Year & Author(s) & Country & Study/Article \\
\hline 2010 & $\begin{array}{l}\text { Associação Portuguesa } \\
\text { dos Administradores } \\
\text { Judiciais }\end{array}$ & Portugal & $\begin{array}{l}\text { Processo 9/10.6BCPRT - } \\
\text { Tribunal Central Administrativo } \\
\text { Norte }\end{array}$ \\
\hline 2005 & Busa, V. & Italy & $\begin{array}{l}\text { Problematiche fiscali del } \\
\text { fallimento e prospettive di } \\
\text { riforma }\end{array}$ \\
\hline 2010 & $\begin{array}{l}\text { Fernandes, C. M., \& } \\
\text { Mario, P. C. }\end{array}$ & Brazil & $\begin{array}{l}\text { Ensaio sobre a essência } \\
\text { contábil versus a forma } \\
\text { jurídica: (d)efeitos na tributação } \\
\text { de uma massa falida }\end{array}$ \\
\hline 1966 & $\begin{array}{l}\text { Krause S., \&Kapiloff } \\
\text { A. Y. }\end{array}$ & U.S. & $\begin{array}{l}\text { Symposium, creditors' rights, } \\
\text { the bankrupt estate, taxable } \\
\text { income and the trustee in } \\
\text { bankruptcy }\end{array}$ \\
\hline 2012 & Medina, J. R. S. & Spain & $\begin{array}{l}\text { Implicaciones fiscales de la } \\
\text { reforma concursal }\end{array}$ \\
\hline
\end{tabular}

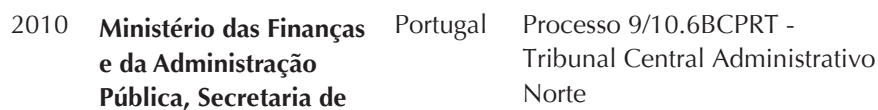
Estado dos Assuntos Fiscais

2002 Moreno-Ternero, J. D. Spain

2000 Newton, G. W.

2012 Tiago, F.
Bankruptcy Rules and Progressive Taxation

U.S. Bankruptcy and Insolvency Accounting Practice and Procedure

Portugal A empresa insolvente mantém a personalidade tributária

\section{Main conclusions}

There is no activity when it is decided for estate settlement of the insolvent debtor and the distribution of the assets obtained among creditors, since the purpose is not profit, but only payment to creditors, so there is no economic operation with a business nature.

Business activity after insolvency should not be liable to taxation.

After bankruptcy, the bankrupt is dispossessed of its assets and the bankrupt estate emerges, as an "accounting entity for the purposes of analyses and controls," but it has no legal personality in the Brazilian positive law and it is also not equal to a "person for tax purposes."

When the bankrupt estate is created, there is a tax directly imposed against property and indirectly against creditors, by reducing their dividend in bankruptcy, so the effect of bankruptcy is transferring the tax burden from debtors to creditors.

By favoring the credit position of public creditors in case of bankruptcy, it ceased safeguarding the position of creditors, which is the main interest of insolvency proceedings, in order to prioritize the public interest, which comes out favored at the expense of the economic operators.

Compliance with tax liability standards, even at the phase of an insolvent company's settlement of assets, will have nothing extraordinary in the light of the principles underlying taxation liable to the IRC.

The issue of bankruptcy is the fact that there must be assigned a certain amount of a divisible good when a company has not enough to meet the requirements of all creditors.

The effect of tax on certain transactions may impose greater difficulties to entities that are undergoing insolvency, as per se in a weak financial position.

In companies declared as insolvent, it is not the fact of being a universal settlement of assets and faced with a deficient economic situation that prevents observing fortuitous and unexpected revenue gain, sales of goods for amounts that can not only pay all debts, but generate surpluses, equity increase. As such, no reason remains to evade taxation regarding the IRC. The taxable profit of an insolvent company is, however, determined in relation to the entire settlement period of the company's equity.

Many of the problems that arise for identifying the treatment applicable to fiscal proceedings occur due to an overlap between tax legislation and the bankruptcy law.
Problematiche fiscali del fallimento e prospettive di riforma

the bankruptcy law.


Thus, subsequently, we evaluate the perception of IA, the TA, and CM about the taxation of insolvent companies regarding the IRC, in Portugal. We intend to quali- tatively assess the various opinions and identify the variables that enable us to conclude whether the insolvent estate is liable to the IRC.

\section{EMPIRICAL STUDY}

After establishing the theoretical framework and reviewing the literature, this part consists in introducing the research methodology and showing data analysis. The choice of a qualitative approach (interpretive perspective) for this study has to do with the fact that it aims to understand the meanings assigned by subjects to their actions in a given context, something which enables interpretation instead of measurement, it is opposed to a quantitative approach (positivist perspective), seeking information through quantitative data.

\subsection{Study Objectives and Research Hypotheses}

At this stage, we seek answers to the following questions: Will insolvent companies be liable to taxation in Portugal? Should the CIRE be amended in order to clearly state whether the settlement of assets of an insolvent estate is liable to the IRC? Should the CIRC be amended and include a chapter specially devote to the subject of taxation in insolvency?

Consequently, the aim of our study is obtaining empirical evidence of the Portuguese reality that enable concluding whether there is a foundation for taxation regarding the IRC of insolvent companies and need to change the legislation applicable to insolvent companies.

To achieve the goals set, we have formalized the research hypotheses to be tested, which largely stem from the literature review previously conducted. We define our research hypotheses in view of the objectives and problems identified by our study. Thus, we have:

Hypothesis 1: The insolvent estate pursues a business activity.

In many situations, it is possible to observe that the IA think there is no business activity when a decision is made to seek settlement of insolvent assets, since the purpose of sharing the outcome obtained among creditors is not profit, but only payment to creditors, thus operations having an economic nature are not realized. So, our objective is evaluating whether the bankrupt estate pursues a business activity.

Hypothesis 2: The outcome of settlement of the insolvent estate is revenue gain.

Given the concept of revenue gain for the purposes of the IRC, and since wealth increase is the very object of taxation, according to the TA, on the grounds that the insolvent estate obtains revenue gain, it will not be exempted from payment of any tax, we intend to know whether the outcome of settlement of insolvent assets will be regarded as revenue gain.
Hypothesis 3: The insolvent estate is liable to the IRC and it has contributory/economic capacity.

If we take into account that the IRC is not a capitation $\operatorname{tax}^{2}$ and that taxes cannot be required just for the simple fact a society exists and there is a need to consider its economic capacity, we intend to ascertain to what extent the bankrupt estate is able to pay taxes and whether it is liable to the IRC.

Hypothesis 4: The bankruptcy law lacks harmonization with the fiscal legislation.

Taking as a starting point the regulatory framework and the literature review of this study, addressed in the first part, it is possible to see that the controversy associated with the taxation issue of insolvent companies is essentially related to lack of harmonization between the bankruptcy law and tax legislation. Then, we aim to evaluate whether liability to the IRC of insolvent companies may have various interpretations in the standards under study.

\subsection{Methodology and Sample Characterization}

The hypotheses we defined above have as their assumptions and population IA, the TA, and CM. Our analysis was based on the population of IA in Portugal, the chiefs, service directors, and finance directors of the TA, and Portuguese CM. As a starting point for data collection, the database of IA was used, obtained from the Comissão de Apreciação e Controlo da Atividade dos Administradores da Insolvência (CACAAI) [Commission for Assessment and Control of the Activity of Insolvency Administrators], the database of electronic addresses of the tax services of the TA, and the database of contacts of the Portuguese courts, provided by the Direção Geral da Administração da Justiça (DGAJ) [General Direction of Justice Administration].

The information collection technique was applied by using electronic questionnaires, created and sent through the software LimeSurvey. According to Kawk and Radler (2002), the choice of this methodology is based on relative efficacy - cost, since the use of questionnaires allows obtaining good results with low cost, enabling the treatment of a large amount of information.

The questionnaire sent to respondents was divided into two sections common to the three groups and a section only for the group of IA. The first section addressed biographical data and characterization of the academic and professional profile. The second section addressed specific aspects of professional performance, regarding the bankruptcy proceedings. The section only for the group of IA addressed 
appointments in insolvency proceedings. The first group of questions intended to gather information on respondents' biographical data, such as gender, educational level and academic degree, supplementary professional training, work experience, certifications or official accreditations achieved, as well as the district serving as workplace. This analysis allowed us to analyze the various opinions of respondents according to their biographical data. Regarding the second group, it comprised a set of questions with a broader scope and, as a consequence, one part of the questionnaire was crucial for further analysis of results, aimed at framing the opinion of these professional groups on the theme of taxation of insolvent companies. This part of the questionnaire was aimed at gathering an opinion of professionals under study, which might subsequently enable comparing the opinion between the three groups of respondents, based on specific aspects of profession performance. Finally, the third group of questions intended to obtain information on the actual experience of the professional class of IA within their professional performance, and the questions are aimed, like the earlier parts of the questionnaire, at the goal we have set.

Questionnaires were individually mailed to the entire population of respondents, a total of 1,150 individuals. We excluded 132 questionnaires because 70 of them were incomplete and the other 62 were not fully filled in. After this procedure, we obtained 126 questionnaires fully filled in, corresponding to a response rate of $10.96 \%$, which we regard as reasonable ${ }^{3}$. Thus, our sample consisted of 126 observations.

Briefly, in Table 2, it is possible to visualize our sample and the respective response rate.

Table 2 Sample and response rate

\begin{tabular}{lccc}
\hline Actors in insolvency proceedings & Population & Sample & Response rate \\
\hline Insolvency administrators & 310 & 48 & $15.48 \%$ \\
Tax and customs authority & 415 & 43 & $10.36 \%$ \\
Court magistrates & 425 & 35 & $8.24 \%$ \\
Total & $\mathbf{1 , 1 5 0}$ & $\mathbf{1 2 6}$ & $\mathbf{1 0 . 9 6 \%}$ \\
\hline
\end{tabular}

Source: Prepared by the authors.

Our research is classified as an exploratory study. The sample obtained does not consist in a representative sample nor in a random sample derived from an experimental design, therefore, it does not allow generalizations. Thus, even if hypothesis testing is used to test population parameters through sampling statistics, their use in our study might not make much sense, using simple statistics would be enough, such as, e.g. frequency distribution tables, in order to reach the same conclusions. However, we think that, in an integrated manner, either for analyzing how the study groups behave with each other or for seeing in an absolutely clear way the position of each group in relation to our research hypotheses, the "chi-square" test ( $\chi 2)$ for independence, and the binomial test better exposes this information.

\subsection{Analysis and Discussion of Results}

After completing data collection, the information undergoes analysis, by using the version 20 of the software Statistical Package for the Social Sciences (SPSS). All tests were made with a $5 \%$ significance level. The statistical methodology to process data was the most accurate, resorting to the use of rather appropriate statistical tests to approach the information collected (Miles \& Huberman, 1994).

\subsubsection{Bivariate analysis: "chi-square" test for inde- pendence.}

In this study, and for this analysis, we took three groups into account, which are related to the profession pursued by respondents, where G1 corresponds to IA, G2 to the TA, and G3 to CM; $\chi 2$ is used to evaluate the association between two qualitative variables $\mathrm{X}$ and $\mathrm{Y}$. The hypotheses of this test are: $\mathrm{H}_{0}$ (null hypothesis): there is no difference in behavior between the groups with regard to a certain specified variable (the groups behave similarly or dependently); $\mathrm{H}_{1}$ (alternative hypothesis): there is difference in behavior between the groups with regard to a determined variable (groups behave independently in relation to the determined variable). It may be said that two groups behave similarly if differences between the observed and expected frequencies in each category are very small. If $P$ $<0.05(\alpha=$ significance $)$ rejects the null hypothesis $\left(\mathrm{H}_{0}\right)$ that there is no difference in behavior between the groups with regard to a particular variable. We display the results of $\chi^{2}$ for independence in Table 3. 
Table 3

$x^{2}$ for independence (variable profession)

\begin{tabular}{|c|c|c|c|c|c|c|c|c|c|c|c|c|}
\hline \multirow[b]{4}{*}{ Variables } & \multicolumn{12}{|c|}{ Chi-square tests } \\
\hline & \multicolumn{12}{|c|}{ Pearson chi-square } \\
\hline & \multicolumn{3}{|c|}{ G1-G2-G3 } & \multicolumn{3}{|c|}{ G1-G3 } & \multicolumn{3}{|c|}{ G1-G2 } & \multicolumn{3}{|c|}{ G2-G3 } \\
\hline & Value & df & $\begin{array}{l}\text { Asymp. Sig. } \\
\text { (2-sided) }\end{array}$ & Value & df & $\begin{array}{l}\text { Asymp. Sig. } \\
\text { (2-sided) }\end{array}$ & Value & df & $\begin{array}{l}\text { Asymp. Sig. } \\
\text { (2-sided) }\end{array}$ & Value & df & $\begin{array}{l}\text { Asymp. Sig. } \\
\text { (2-sided) }\end{array}$ \\
\hline $\begin{array}{l}\text { Business activity of the } \\
\text { insolvent estate }\end{array}$ & 44.239 & 2 & $<0.001$ & 15.971 & 1 & $<0.001$ & 44.531 & 1 & $<0.001$ & 8.026 & 1 & 0.005 \\
\hline $\begin{array}{l}\text { Settlement of insolvent assets } \\
\text { is revenue gain }\end{array}$ & 58.332 & 2 & $<0.001$ & 5.656 & 1 & 0.017 & 55.484 & 1 & $<0.001$ & 27.129 & 1 & $<0.001$ \\
\hline $\begin{array}{l}\text { Liability to the IRC of the } \\
\text { insolvent estate }\end{array}$ & 51.32 & 2 & $<0.001$ & 8.174 & 1 & 0.004 & 47.831 & 1 & $<0.001$ & 18.356 & 1 & $<0.001$ \\
\hline $\begin{array}{l}\text { Ability of the insolvent estate } \\
\text { to pay }\end{array}$ & 55.526 & 2 & $<0.001$ & 13.668 & 1 & $<0.001$ & 55.333 & 1 & $<0.001$ & 16.196 & 1 & $<0.001$ \\
\hline $\begin{array}{l}\text { Amending the legal regime } \\
\text { (CIRE) }\end{array}$ & 21.451 & 6 & 0.002 & 7.172 & 3 & 0.067 & 7.172 & 3 & 0.067 & 5.815 & 3 & 0.121 \\
\hline Change of the CIRC & 18.656 & 6 & 0.005 & 10.412 & 3 & 0.015 & 10.412 & 3 & 0.015 & 3.559 & 3 & 0.313 \\
\hline No. valid cases & 126 & & & 83 & & & 91 & & & 78 & & \\
\hline
\end{tabular}

Source: Prepared by the authors.

By analyzing Table 3, we observe that when comparing two groups, G1 and G3, there were no differences in the variable "change to the legal regime" and all the other differences between the remaining variables were significant. Specifically, it is concluded that only in the variable "change to the legal regime" the groups G1 and G3 have a similar behavior.

Between G2 and G3, only in the variables "amending the legal regime" and "change to the CIRC" there is no variation, where groups have no behavioral differences.

Between G1 and G2 all differences are significant, except for the variable "change to the legal regime", where groups behave similarly.

We test below the hypotheses of our research.

\subsubsection{Testing the general study hypothesis: bino- mial test.}

At this phase, our analysis is conducted to meet the research objectives and to compare and contrast data and evidence, in order to reject or not our research hypotheses. Taking into account the research methodology adopted, confirmation or denial of the hypotheses prepared consists in evaluating whether the results obtained in the study of each professional classes under analysis (through a survey) are in line with the regulatory framework and the literature review that we define and approach theoretically.

Hence, our focus, in this part of the study, lies on identifying the factors that may be associated with the analysis of taxation of insolvent companies. For this analysis, we used the binomial test, because we intend to analyze variables having a nominal nature with two categories only. It is useful to check whether the success rate observed in the sample may belong to a population with a given $p$ value. The proportion to be tested is $50 \%{ }^{4}$. Thus, we may interpret $p$ value as the smallest value of the significance level for which we reject $\mathrm{H}_{0}$ (null hypothesis). In this way, if $p$ value was greater than the significance level $(\alpha)$ proposed for the test, we do not reject $\mathrm{H}_{0}$. All tests were prepared with a $5 \%$ significance level. So, we intend to test, among the 3 study groups, the perception of the various respondents about the theme under study. Using the binomial test will serve us to confirm the absolutely clear position of each group in relation to our research hypotheses ${ }^{5}$. Thus, the hypothesis tested is whether there is a clear attitude among individuals in each group, i.e. if they act the same way.

Let us consider the variable: Business activity of the insolvent estate. There was a question for the three sets of individuals, namely: IA, referred to as G1 in Table 4; TA, named as G2; and CM, named as G3. Each of these sets was divided into two groups: Group 1 - Yes, named as Group 1 in Table 4; Group 2 - No, named as Group 2. Group 1 (Yes) thinks that the insolvent estate pursues a business activity. Group 2 (No) thinks that the insolvent estate does not pursue a business activity.

The variable is: the insolvent estate pursues a business activity.

The hypotheses are:

$\mathrm{H}_{0}$ : There is no significant difference in the proportions between Group 1 (Yes) and Group 2 (No), within each group, namely: IA (or G1), TA (or G2), and CM (or G3) (null hypothesis).

$\mathrm{H}_{\mathrm{A}}$ : There is a significant difference in the proportions between Group 1 (Yes) and Group 2 (No), within each group, namely: IA (or G1), TA (or G2), and CM (or G3) (alternative hypothesis). 


\begin{tabular}{|c|c|c|c|c|c|c|c|c|c|c|c|c|c|c|c|c|}
\hline \multirow{2}{*}{$\begin{array}{l}\text { Binomial test } \\
\text { Variable }\end{array}$} & & \multicolumn{5}{|c|}{ G1 } & \multicolumn{5}{|c|}{ G2 } & \multicolumn{5}{|c|}{ G3 } \\
\hline & & Cat. & $\mathbf{N}$ & $\begin{array}{l}\text { Obs. } \\
\text { Prop. }\end{array}$ & $\begin{array}{l}\text { Test } \\
\text { Prop. }\end{array}$ & $\begin{array}{l}\text { Exact Sig. } \\
\text { (2-tailed) }\end{array}$ & Cat. & $\mathbf{N}$ & $\begin{array}{l}\text { Obs. } \\
\text { Prop. }\end{array}$ & $\begin{array}{l}\text { Test } \\
\text { Prop. }\end{array}$ & $\begin{array}{l}\text { Exact Sig. } \\
\text { (2-tailed) }\end{array}$ & Cat. & $\mathbf{N}$ & $\begin{array}{l}\text { Obs. } \\
\text { Prop. }\end{array}$ & $\begin{array}{l}\text { Test } \\
\text { Prop. }\end{array}$ & $\begin{array}{l}\text { Exact Sig } \\
\text { (2-tailed) }\end{array}$ \\
\hline \multirow{3}{*}{$\begin{array}{l}\text { Business } \\
\text { activity of } \\
\text { the insolvent } \\
\text { estate }\end{array}$} & Group 1 & Yes (1) & 3 & 0.06 & 0.50 & $<0.001$ & Yes (1) & 32 & 0.74 & 0.50 & 0.002 & Yes (1) & 15 & 0.43 & 0.50 & 0.500 \\
\hline & Group 2 & No (2) & 45 & 0.94 & & & No (2) & 11 & 0.26 & & & No (2) & 20 & 0.57 & & \\
\hline & Total & & 48 & 1.00 & & & & 43 & 1.00 & & & & 35 & 1.00 & & \\
\hline
\end{tabular}

Source: Prepared by the authors.

The result of binomial test in the case of G3 indicates that $p=50 \%$, so we do not reject $\mathrm{H}_{0}$. This means there are no significant statistical evidence that lead us to believe that the proportion of CM respondents that think the insolvent estate does not pursue a business activity is significantly different from that of respondents who think it pursues.

In turn, for G1 and G2, and because $p<1 \%$, we reject $\mathrm{H}_{0}$, and we observed that IA respondents have a clear position regarding the fact they think the insolvent estate does not pursue a business activity, unlike TA respondents, who have a clear position about the fact they think the insolvent estate pursues a business activity.

Since there are differences of opinion among the three groups, we are unable to validate our research hypothesis: Hypothesis 1: The insolvent estate pursues a business activity.

Let us consider the variable: Settlement of insolvent assets is revenue gain. There was a question for the three sets of individuals, namely: IA, named as G1 in Table 5; TA, named as G2; and CM, named as G3. Each of the sets of respondents was divided into two groups: Group 1 (Yes), named in Table 5 Group 1; Group 2 (No), named as Group 2. Group 1 (Yes) thinks the settlement of insolvent assets is revenue gain. Group 2 (No) does not think the settlement of insolvent assets is revenue gain.

The variable is: settlement of insolvent assets is revenue gain.

The hypotheses are:

$\mathrm{H}_{0}$ : There is no significant difference in the proportions between Group 1 (Yes) and Group 2 (No), within each group, namely: IA (or G1), TA (or G2), and CM (or G3) (null hypothesis).

$\mathrm{H}_{\mathrm{A}}$ : There is a significant difference in the proportions between Group 1 (Yes) and Group 2 (No), within each group, namely: IA (or G1), TA (or G2), and CM (or G3) (alternative hypothesis).

\begin{tabular}{|c|c|c|c|c|c|c|c|c|c|c|c|c|c|c|c|c|}
\hline \multirow{2}{*}{$\begin{array}{l}\text { Binomial test } \\
\text { Variable }\end{array}$} & & \multicolumn{5}{|c|}{ G1 } & \multicolumn{5}{|c|}{ G2 } & \multicolumn{5}{|c|}{ G3 } \\
\hline & & Cat. & $\mathbf{N}$ & $\begin{array}{l}\text { Obs. } \\
\text { Prop. }\end{array}$ & $\begin{array}{l}\text { Test } \\
\text { Prop. }\end{array}$ & $\begin{array}{l}\text { Exact Sig. } \\
\text { (2-tailed) }\end{array}$ & Cat. & $\mathbf{N}$ & $\begin{array}{l}\text { Obs. } \\
\text { Prop. }\end{array}$ & $\begin{array}{l}\text { Test } \\
\text { Prop. }\end{array}$ & $\begin{array}{l}\text { Exact Sig. } \\
\text { (2-tailed) }\end{array}$ & Cat. & $\mathbf{N}$ & $\begin{array}{l}\text { Obs. } \\
\text { Prop. }\end{array}$ & $\begin{array}{l}\text { Test } \\
\text { Prop. }\end{array}$ & $\begin{array}{l}\text { Exact Sig } \\
\text { (2-tailed) }\end{array}$ \\
\hline \multirow{3}{*}{$\begin{array}{l}\text { Settlement } \\
\text { of insolvent } \\
\text { assets is } \\
\text { revenue gain }\end{array}$} & Group 1 & Yes (1) & 6 & 0.13 & 0.50 & $<0,001$ & Yes (1) & 39 & 0.91 & 0.50 & $<0.001$ & Yes (1) & 12 & 0.34 & 0.50 & 0.090 \\
\hline & Group 2 & No (2) & 42 & 0.88 & & & No (2) & 4 & 0.09 & & & No (2) & 23 & 0.66 & & \\
\hline & Total & & 48 & 1.00 & & & & 43 & 1.00 & & & & 35 & 1.00 & & \\
\hline
\end{tabular}

Source: Prepared by the authors.

For G1 and G2, and because $p<1 \%$, we reject $\mathrm{H}_{0}$. This means there is significant statistical evidence that lead us to believe that the proportion of IA and TA respondents who think the outcome of settlement of the insolvent estate is revenue gain is significantly different from that of respondents who think it is not revenue gain. Specifically, IA respondents have a clear position concerning the fact the outcome of settlement of the insolvent estate is not revenue gain, unlike TA respondents, who have a clear position about the fact they think the outcome of settlement of the insolvent estate is revenue gain.
The result of binomial test in the case of G3 indicates that $p=9 \%$, so we do not reject $\mathrm{H}_{0}$. This means there is no reason to doubt that the proportion of $\mathrm{CM}$ respondents who have the opinion that the outcome of settlement of the insolvent estate is revenue gain is significantly different from that of respondents who think it is not revenue gain.

As there are differences between the groups, we are unable to validate our research hypothesis: Hypothesis 2: The outcome of settlement of the insolvent estate is revenue gain.

Let us consider the variables: Liability to the IRC of the insolvent estate and Contributory capacity of the insolvent 
estate. There was a question for the three sets of individuals, namely: IA, named as G1 in Table 6; TA, named as G2; and $\mathrm{CM}$, named as G3. Each of these sets was divided into two groups: Group 1 (Yes) named in Table 6 Group 1; Group 2 (No), named Group 2. Group 1 (Yes) thinks the insolvent estate is passively liable to the IRC and the insolvent estate has contributory capacity. Group 2 (No) does not think the insolvent estate is passively liable to the IRC and the insolvent estate has not contributory capacity.

The variables are: the insolvent estate is passively liable to the IRC and the estate has contributory capacity.

The hypotheses are:

$\mathrm{H}_{0}$ : There is no significant difference in the proportions between Group 1 (Yes) and Group 2 (No), within each group, namely: IA (or G1), TA (or G2), and CM (or G3) (null hypothesis).

$\mathrm{H}_{\mathrm{A}}$ : There is a significant difference in the proportions between Group 1 (Yes) and Group 2 (No), within each group, namely: IA (or G1), TA (or G2), and CM (or G3) (alternative hypothesis).

Table 6 Variables binomial test: liability to the IRC and contributory capacity of the insolvent estate

\begin{tabular}{|c|c|c|c|c|c|c|c|c|c|c|c|c|c|c|c|c|}
\hline \multirow{2}{*}{$\begin{array}{l}\text { Binomial test } \\
\text { Variable }\end{array}$} & & \multicolumn{5}{|c|}{ G1 } & \multicolumn{5}{|c|}{ G2 } & \multicolumn{5}{|c|}{ G3 } \\
\hline & & Cat. & $\mathbf{N}$ & $\begin{array}{l}\text { Obs. } \\
\text { Prop. }\end{array}$ & $\begin{array}{l}\text { Test } \\
\text { Prop. }\end{array}$ & $\begin{array}{l}\text { Exact Sig. } \\
\text { (2-tailed) }\end{array}$ & Cat. & $N$ & $\begin{array}{l}\text { Obs. } \\
\text { Prop. }\end{array}$ & $\begin{array}{l}\text { Test } \\
\text { Prop. }\end{array}$ & $\begin{array}{l}\text { Exact Sig. } \\
\text { (2-tailed) }\end{array}$ & Cat. & $N$ & $\begin{array}{l}\text { Obs. } \\
\text { Prop. }\end{array}$ & $\begin{array}{l}\text { Test } \\
\text { Prop. }\end{array}$ & $\begin{array}{l}\text { Exact Sig. } \\
\text { (2-tailed) }\end{array}$ \\
\hline \multirow{3}{*}{$\begin{array}{l}\text { Liability to } \\
\text { the IRC of } \\
\text { the insolvent } \\
\text { estate }\end{array}$} & Group 1 & Yes (1) & 2 & 0.04 & 0.50 & $<0.001$ & Yes (1) & 32 & 0.74 & 0.50 & 0.002 & Yes (1) & 9 & 0.26 & 0.50 & 0.006 \\
\hline & Group 2 & No (2) & 46 & 0.96 & & & No (2) & 11 & 0.26 & & & No (2) & 26 & 0.74 & & \\
\hline & Total & & 48 & 1.00 & & & & 43 & 1.00 & & & & 35 & 1.00 & & \\
\hline \multirow{3}{*}{$\begin{array}{l}\text { Contributory } \\
\text { capacity of } \\
\text { the insolvent } \\
\text { estate }\end{array}$} & Group 1 & Yes (1) & 4 & 0.08 & 0.50 & $<0.001$ & Yes (1) & 37 & 0.86 & 0.50 & $<0.001$ & Yes (1) & 15 & 0.43 & 0.50 & 0.500 \\
\hline & Group 2 & No (2) & 44 & 0.92 & & & No (2) & 6 & 0.14 & & & No (2) & 20 & 0.57 & & \\
\hline & Total & & 48 & 1.00 & & & & 43 & 1.00 & & & & 35 & 1.00 & & \\
\hline
\end{tabular}

Source: Prepared by the authors.

For the variable liability to the IRC of the insolvent estate, the result of the binomial test indicates that the test value associated with the test is $<1 \%$ in G1, G2, and G3, so we reject $\mathrm{H}_{0}$. Specifically, this means that the IA and $\mathrm{CM}$ respondents have a clear position that the insolvent estate should not be liable to the IRC and TA respondents that the insolvent estate should be liable to the IRC.

For the variable contributory capacity of the insolvent estate, the result of binomial test in the case of G3 indicates that $p=50 \%$, so we do not reject $\mathrm{H}_{0}$. This means that there is no reason to doubt that the proportion of $\mathrm{CM}$ respondents who have the opinion that the insolvent estate has contributory capacity is significantly different from that of respondents who think it has no contributory capacity. For G1 and G2, the probative value associated with the test is $<1 \%$. Thus, for the $5 \%$ significance level (a), we reject $\mathrm{H}_{0}$. This means we may conclude that IA and TA respondents have a clear position by considering, respectively, that the insolvent estate has no contributory capacity or it has contributory capacity.

Since there are differences between the groups, we are unable to validate our research hypothesis: Hypothesis 3:
The insolvent estate is liable to the IRC and it has contributory/economic capacity.

Consider the variables: change in the CIRE and change in the CIRC. There was a question for the three sets of individuals, namely: IA, named as G1 in Table 7; TA, named as G2; and CM, named as G3. Each of these sets was divided into two groups: Group 1 (Yes), named in Table 7 Group 1; Group 2 (No), named as Group 2. Group 1 (Yes) thinks that the CIRE and the CIRC should be changed. Group 2 (No) does not think the CIRE and the CIRC should be changed.

The variables are: changing the CIRE and changing the CIRC.

The hypotheses are:

$\mathrm{H}_{0}$ : There is no significant difference in the proportions between Group 1 (Yes) and Group 2 (No), within each group, namely: IA (or G1), TA (or G2), and CM (or G3) (null hypothesis).

$\mathrm{H}_{\mathrm{A}}$ : There is a significant difference in the proportions between Group 1 (Yes) and Group 2 (No), within each group, namely: IA (or G1), TA (or G2), and CM (or G3) (alternative hypothesis). 


\begin{tabular}{|c|c|c|c|c|c|c|c|c|c|c|c|c|c|c|c|c|}
\hline \multicolumn{17}{|l|}{ Binomial test } \\
\hline \multirow[b]{2}{*}{ Variable } & & \multicolumn{5}{|c|}{ G1 } & \multicolumn{5}{|c|}{ G2 } & \multicolumn{5}{|c|}{ G3 } \\
\hline & & Cat. & $\mathbf{N}$ & $\begin{array}{l}\text { Obs. } \\
\text { Prop. }\end{array}$ & $\begin{array}{l}\text { Test } \\
\text { Prop. }\end{array}$ & $\begin{array}{l}\text { Exact Sig. } \\
\text { (2-tailed) }\end{array}$ & Cat. & $\mathbf{N}$ & $\begin{array}{l}\text { Obs. } \\
\text { Prop. }\end{array}$ & $\begin{array}{l}\text { Test } \\
\text { Prop. }\end{array}$ & $\begin{array}{l}\text { Exact Sig. } \\
\text { (2-tailed) }\end{array}$ & Cat. & $\mathbf{N}$ & $\begin{array}{l}\text { Obs. } \\
\text { Prop. }\end{array}$ & $\begin{array}{l}\text { Test } \\
\text { Prop. }\end{array}$ & $\begin{array}{l}\text { Exact Sig. } \\
\text { (2-tailed) }\end{array}$ \\
\hline \multirow{3}{*}{$\begin{array}{l}\text { Amending } \\
\text { the legal } \\
\text { regime (CIRE) }\end{array}$} & Group 1 & Yes (1) & 38 & 0.79 & 0.50 & $<0,001$ & Yes (1) & 41 & 0.95 & 0.50 & $<0.001$ & Yes (1) & 28 & 0.80 & 0.50 & 0.001 \\
\hline & Group 2 & No (2) & 10 & 0.21 & & & No (2) & 2 & 0.05 & & & No (2) & 7 & 0.20 & & \\
\hline & Total & & 48 & 1.00 & & & & 43 & 1.00 & & & & 35 & 1.00 & & \\
\hline \multirow{3}{*}{$\begin{array}{l}\text { Changing the } \\
\text { CIRC }\end{array}$} & Group 1 & Yes (1) & 36 & 0.75 & 0.50 & 0.001 & Yes (1) & 37 & 0.86 & 0.50 & $<0.001$ & Yes (1) & 24 & 0.69 & 0.50 & 0.041 \\
\hline & Group 2 & No (2) & 12 & 0.25 & & & No (2) & 6 & 0.14 & & & No (2) & 11 & 0.31 & & \\
\hline & Total & & 48 & 1.00 & & & & 43 & 1.00 & & & & 35 & 1.00 & & \\
\hline
\end{tabular}

Source: Prepared by the authors.

In both variables, changing the CIRE and changing the CIRC, the result of the binomial test for G1, G2, and G3 indicates that $p<\alpha$, so we reject $\mathrm{H}_{0}$. This means we may conclude that there are reasons to doubt that the opinion of respondents (IA, TA, CM) who think the CIRE and the CIRC should not be changed is in the same proportion of respondents who think the CIRE and the CIRC should be changed. Specifically, IA, TA, and CM have a clear position on the fact they think it is very important that the CIRE and the CIRC are changed, either to explain clearly whether settlement of the insolvent estate assets is liable to the IRC or to assign a chapter especially devoted to the theme of taxation in insolvency.

Due to the position agreement between the three groups, it is possible to validate our research hypothesis: Hypothesis 4: The bankruptcy law lacks harmonization with the fiscal legislation.

At this phase we are able to summarize the results of our research and make it clear whether the objectives have been met and our hypotheses have been confirmed or rejected, in order to provide answers to our research questions.

\section{CONCLUDING REMARKS}

We began this study convinced that we could provide answers to our research questions. The methodology adopted in gathering information was the use of questionnaires, created through the software LimeSurvey, and emailed to the professional classes covered by this study (IA, TA, CM). The response rate was $10.96 \%$, something which is partly justified by the fact the questionnaires were sent within a period coinciding with the respondents' vacation. However, even though they were sent only twice, they had the validity of a month and many respondents did not regard the link as safe, whence they did not complete their answers. In order to extend this study in the future, to ensure a good level of response rate, the questionnaires should be sent more frequently and they need a longer validity period, as well as a prior contact to the entities must be made.

Still, we obtained a total of 126 responses, where $38.1 \%$ of the answers are from IA (48 responses), 34.1\% are from the TA (43 responses), and $27.8 \%$ are from CM (35 responses), something which has provided a response rate regarded as reasonable. We think there was no impact of the response rate on the results analyzed, as we intended to evaluate empirical evidence in Portugal, particularly in terms of taxation of insolvent companies regarding the IRC.

Given the results obtained, by means of the various tests of our variables, we think that, although the methodology used requires caution in the conclusions, just as in terms of generalizing the results obtained to the population, above all due to the fact we have received only about $11 \%$ of responses, when we aimed to gather information from the universe concerned, it is clear that there is no empirical evidence that allow us to reject the hypotheses prepared. Similarly, we also cannot confirm them. However, it is possible to suggest the answers to our research questions, taking into account the results obtained and analyzed.

Regarding the study hypotheses, the results are shown below.

The IA and CM respondents clearly believe that the insolvent estate should not be liable to the IRC (respectively, $96 \%$ and $74 \%$ ) and TA respondents pointed out that 
the insolvent estate should be liable to the IRC (74\%). The IA respondents (94\%) objectively think the insolvent estate does not pursue a business activity, unlike TA respondents (74\%), who have a clear position about the fact that they think the insolvent estate pursues an economic activity. In turn, CM respondents do not have an objective opinion in this regard. IA respondents (88\%) clearly think the outcome of the settlement of the insolvent estate should not be revenue gain, unlike TA respondents (91\%), who think it is revenue gain. CM respondents do not have an objective position in this regard. IA and TA respondents (respectively, 92\% and 86\%) have a clear opinion as they think, respectively, the insolvent estate has not contributory capacity or it has contributory capacity. CM respondents do not have a clear idea in this regard. Respondents (IA, TA, CM) have an objective thinking about the fact they regard as very important that the CIRE and the CIRC are amended, now to explain clearly whether settlement of assets of an insolvent estate is liable to the IRC (respectively, 79\%, 95\%, and $80 \%$ ), then to then to assign a chapter specifically devoted to the subject of ta- xation on insolvency (respectively, 75\%, 86\%, and 69\%).

Taking into account the results obtained, even if we cannot answer the question about taxation regarding the IRC of insolvent companies, and considering the results analyzed, we think the fiscal system is not simplified in this subject of taxation of insolvent companies, thus we conclude it is very interesting and useful amending the CIRE and the CIRC for a rather specific approach to tax in insolvency proceedings, in order to settle all disputes that still coexist.

Our paper is an analysis of taxation of insolvent companies regarding the IRC.

Insolvency proceedings also encompasses, as it is known, other taxes, as well as various kinds of costs to the State.

Through this paper and the analysis of the tax regime of insolvent companies, we hope to have contributed to make such a controversial theme clearer, which involves the various agents in the insolvency proceedings in Portugal (IA, TA, CM).

Thus, we hope this is just a first paper within a set of further research studies.

\section{References}

Dinis, A. C. S. A., Lopes, C. M. M., Marcelino, P. M. J. (2014). As sociedades insolventes e a tributação em sede de imposto sobre o rendimento das pessoas colectivas (IRC) em. Portugal. Revista de Finanças Públicas e Direito Fiscal, 7(2), 113-142.

Escolà, M. E. (2004). New Bankruptcy Act in Spain. Recuperado de http://www.imakenews.com/iln/new_bankruptcy_act_spain.pdf

Fernandes, C. M., \& Mario, P. C. (2010). Ensaio sobre a essência contabil versus a forma jurídica: (d)efeitos na tributação de uma massa falida. Recuperado de http://www.congressousp.fipecafi.org/ artigos 102010/453.pdf

Kawk, N., \& Radler, B. (2002). A comparison between mail and web surveys: response pattern, respondent profile, and data quality. Recuperado de http://www.jos.nu/Articles/article.asp

Krause, S., \& Kapiloff, A. Y. (1966). Symposium, creditors' rights, the bankrupt estate, taxable income and the trustee in bankruptcy. Recuperado de http://ir.lawnet.fordham.edu/cgi/viewcontent. cgi article $=1859 \&$ context $=$ flr .

Lopes, C. M. M. (2008). Quanto custa pagar impostos em Portugal? Coimbra: Almedina.

Marques, L. A. (2005). O. tributo e o seu tratamento no novo regime jurídico de insolvência empresarial. Recuperado de www.miggo, com.br/imgarq/176/248700_533.doc

Medina, J. R. S. (2012). Implicaciones fiscales de la reforma concursal Recuperado de http://www.diariojuridico.com/implicacionesfiscales-de-la-reforma-concursal/

Miles, B. M., \& Huberman, A. M. (1994). A expanded sourcebook qualitative data analysis (2. ed.). Thousand Oaks, CA: Sage.

Moreno-Ternero, J. D. \& Villar, A. (2002). Bankruptcy rules and progressive taxation. Recuperado de http://www.researchgate. -net/publication/5134429_BANKRUPTCY_RULES_AND_ PROGRESSIVE_TAXATION
Moss, J., \& Hendry, G. (2002). Use of electronic surveys in course evaluation. British Journal of Educational Technology, 33(5), 583-592.,

Newton, G.w. (2000). Bankruptcy and insolvency accounting practice and procedure (Vol. 1, 6. ed.). Hoboken, NJ: John Wiley \& Sons.

Portugal. (2003, 29 de outubro). Processo 01079/03. Lisboa, Portugal: Recuperado de http://www.dgsi.pt/jsta.nsf/35fbbbf22elbble680256f 8e003ea931/32e17fdc3a9cbdfc80256dea003ec11b?OpenDocument\& ExpandSection $=1$

Portugal. (2007, 18 de abril). Processo 236/03.2TYVNG. Vila Nova de Gaia, Portugal.

Portugal. (2010, 2 de dezembro). Regime jurídico da insolvência e recuperação de empresas: estudo de avaliação sucesșiva. Lisboa: Direção-Geral da Política de Justiça. Recuperado de http://www. dgpj.mj.pt/sections/politica-legislativa/anexos-pendencias/sections/ politica-legislativa/anexos-pendencias/anexo-iv-estudo-dezembro/ downloadFile/file/AnexoIV_Relatorio_Insolvencias.pdf

Portugal. (2010, 16 de dezembro). Processo 9/10.6BCPRT. Porto: - Tribunal Central Administrativo Norte. Recuperado de http://www. apaj.pt/ficheiros/oposicao_da_accao_principal.pdf

Santos, J. A. (2003). Teoria fiscal. Lisboa: Universidade Técnica dé Lisboa.

Spadotto, R. D. C. (2005). A venda de bens da massa falida e sua respetiva tributação sob a ótica da nova lei de falências. Recuperado de http://www.ibrademp.org.br/arquivos/nova_lei_de_falencias2.pdf

Tiago, F. (2012). A empresa insolvente mantém a personalidade tributária. Recuperado de http://www.vidaeconomica.pt/gen. $\mathrm{pl}$ ? $\mathrm{p}=$ stories\&op=view\&fokey=ve.stories $/ 79852$

Tosi, L. (2005). Problematiche fiscali del fallimento e prospettive di riforma (collana diretta da Francesco Moschetti e Loris Tosi). Torino: CEDAM/AEST.

\section{Correspondence Address:}

Ana Cristina dos Santos Arromba Dinis

Instituto Superior de Contabilidade e Administração de Coimbra

Quinta Agrícola, Bencanta - 3040-316

Coimbra - Portugal

E-mail: ana.arromba.dinis@gmail.com 